of treatment of a condition like the common cold, in which there are no real objective signs by which the patient's subjective feelings can be checked. All the investigators made provisions for this and endeavoured to eliminate the subjective element. The experience thus gained will be of great value when further remedies are presented for test.

Discussing these trials, The Lancet suggests that the good results obtained by Hopkins may have been due to the effects of patulin on the particular organisms responsible for the colds which he treated, or that, in view of patulin's failure in the later Army and Medical Research Council trials, its succoss in the Navy trials was one of those rare events which do sometimes happen.

Whether patulin may yet have other uses, further work will doubtless show.

G. LAPAGE.

\section{THE HEATHER BEETLE}

$\mathrm{T}$ HE British Field Sports Society has recently issued a booklet entitled "Report on the Biology and Control of the Heather Beetle". In view of the damage caused by this insect in the past, this report and its findings will be of very definite interest to those who are concerned with the management and preservation of moorlands. These include not only the moor owner and his shooting tenants, but also the sheep grazier and, to a lesser degree, the bee-keeper. The activities of this beetle deplete the numbers of grouse, impoverish the grazing and decrease the honey-flow. The report under notice is based upon investigations carried out between 1937 and 1940 under the direction and supervision of Dr. A. E. Cameron, of the Department of Agriculture and Forest Zoology, University of Edinbürgh.

The beetle in question is Lochmoea suturalis, a member of the family Chrysomelidæ. Severe damage to the heather is most prevalent in Scotland; it is also troublesome in Germany and Holland. In July and August, the leaves and stems of heather attacked by the larvæ of the beetle become fox-red where they have been chewed and partially stripped of bark, and especially the ends of young shoots. The most severe damage is done to old heather of twenty years or more. Young heather is also attacked but permanent damage rarely happens. Attacks are most prevalent and the beetles most abundant over flat wet moorlands, but well-drained slopes are not often affected. The eggs of the beetle require humid conditions for their development and are chiefly laid on Sphagnum moss. Rainfall in spring and early summer during its breeding season is believed to determine its rate of multiplication. Seasons of very low precipitation seem, on the other hand, to check its activities. There is only one generation in the year. The beetles overwinter in the ground or among moss, etc., and begin to lay eggs in mid-April. Incubation lasts three to four weeks in Nature, and hatching of the larvæ begins early in June when they climb the plants in order to feed on the young shoots and leaves. The adult beetles appear first in the latter half of August but do not become abundant until late in September. Ling heather, Calluna vulgaris, is the chief and perhaps the only food plant of this insect. The only natural enemy of any importance was found to be the ladybird Coccinella hieroglyphida which, however, did not appear to exert any significant degree of control of the beetle.
The problem of dealing with the insect is a question of moorland economics. Treatment of the heather with derris and pyrethrum dusts serves to check the larvæ. General adoption of this method over wide areas of moorland is out of the question owing to the costs of material and labour. Muir-burning in Scotland is not permissible at the time it would be most efficacious. There is no practice of moorland management that should be more encouraged than a tenyear rotational system of burning, since it induces young growth which recevers more quickly from beetle attack than does old heather. Dusting and burning, however, are of secondary importance to drainage. The elimination of excessive moisture by a proper system of surface drains is the only known means by which permanent control of the pest may be achieved.

This report, it may be added, can only be obtained direct from the British Field Sports Society, Petworth, Sussex, price Is. post paid. It is well printed and, with thirteen full-page half-tone plates, is remarkably cheap.

\section{FORTHCOMING EVENTS}

\section{Monday, January I}

ROYAL GEOGRAPHICAL SOCIETY (at Kensington Gore, South Kensington, London, S.W.7), at 2.30 p.m.-Mrs. Harold Ingrams: "Young People of the Hadhramaut" (with films) (Christmas Lecture for Young People).

Tuesday, January 2

ROYAL INSTITUTION (at 21 Albemarle Street, London, W.1), at 2.30 p.m.-Sir Harold Spencer Jones, F.R.S.: "Astronomy in ou Daily Life", 3 : "How we get our Time" (Christmas Lectures).

INSTITUTION OF CIVIL ENGINEERS (WORKS CONSTRUCTION DIVISION) (at Great George Street, Westminster, London, S.W.1), at 5.30 p.m.Lieut.-Colonel C. M. Norrie : "The Organization of Civil Engineering Work".

\section{Wednesday, January 3}

ROYAL SOCIETY of ARTS (at John Adam Street, Adelphi, London, W.C.2) at 1.45 p.m.- - Lieut.-Commander Rupert T. Gould: "The Art of Measuring Time" (Dr. Mann Juvenile Lecture).

\section{Thursday, January 4}

Royal INSTrtution (at 21 Albemarle Street, London, W.1), at 2.30 p.m.-Sir Harold Spencer Jones, F.R.S.: "Astronomy in our Daily Life", 4: "Finding the Longitude" (Christmas Lectures).

\section{Friday, January 5}

ROYAL GEOGRAPHICAL SOCIETY (at Kensington Gore, South Kensington, London, S.W.7), at 2.30 p.m.- -Surgeon-Commander Bingham "Sledging with Dog Teams in the Antarctic" (with films) (Christma Lecture for Young People).

\section{Saturday, January 6}

ROYAI INSTTTUTION (at 21 Albemarle Street, London, W.1), at 2.30 p.m.- -Sir Harold Spencer Jones, F.R.S.: "Astronomy in ou Daily Life", 5 : "Clocks and Time Keeping" (Christmas Lectures).

\section{APPOINTMENTS VACANT}

APPLICATIONS are invited for the following appointments on or before the dates mentioned :

IRRIGATION ENGINEER, Soils Mechanics Laboratory, Irrigation Department, Ceylon-The Ministry of Labour and National Service, Central (T. and S.) Register, Room 5/17, Sardinia Street, Kingsway, London, W.C.2 (quoting Reference No. E.1258.A) (January 1).

INSPECroR OF AGRICULTURz, Sudan Government-The Ministry of INSPECroR OF AGR Service, Centra! (T, and S.) Register, Room 5/17, Sardinia Street, Kingsway, London, W.C.2 (quoting Reference No. F.3285. X A) (January 2)

F.3285.XA) (January 2), EXECUTIVE ENGINEER by the Government of Trinidad-The Ministr. of L 5/17, Sardinia Street, Kings

o. E.1266.A) (January 3). manufacturers engaged on high priority ANALYTICAL CHEMIST for manufacturers engaged on high priorit work, S.E. London area - The Ministry Service, Central (T. and (January 4 .

(January 4).

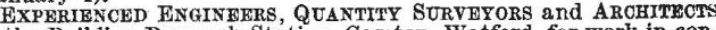
the Bulding Research Station, Garston, Watford, for work in conmith the preparation of codes of practice-The Ministry of 